\title{
Ivo de Figueiredo - Henrik Ibsen: Člověk a maska
}

\author{
Barbara Gregorová
}

Ivo de Figueiredo. Henrik Ibsen. Člověk a maska. Překlad Karolína Stehlíková. Praha: Nakladatelství Karolinum, 2015. $671 \mathrm{~s}$.

Zkrácené vydání norské dvousvazkové biografie Ivo de Figueireda Henrik Ibsen. Člověk (2006) a Henrik Ibsen. Maska (2007), kterou letos na jaře vydalo nakladatelství Karolinum v překladu Karolíny Stehlíkové, je prozatím nejnovějším pokusem o zkoumání ibsenovského světa v 21. století. $\mathrm{V}$ českém prostředí jde o vưbec první překlad velké zahraniční biografie o Henriku Ibsenovi. ${ }^{1}$

$\mathrm{Na}$ norském internetovém portálu Alt om Henrik Ibsen, který spravuje Národní knihovna v Oslu, ${ }^{2}$ se s nadsázkou píše, že „všechny dny Ibsenova života jsou do nejmenšího detailu zkatalogizovány“. ${ }^{3}$ Pod

1 Dosavadní české recepci díla Henrika Ibsena se překladatelka a nordistka Karolína Stehlíková velmi podrobně věnuje v doslovu knihy a jasně prokazuje, že Ibsenovi se kontinuálně věnovala řada literárních kritiků i nordistů od prvních uvedení Ibsenových her po roce 1900. Současné ibsenovské bádání po roce 1989 se však doposud omezilo pouze na dílčí překlady ze zásadních monografií, uveřejňované dramaturgy v programech, které v roce 1999 doplnil překlad Ibsenova lexikonu M. M. Andersové a v roce 2006 sborník Ipsa, Ipsa, Ibsen. První z jmenovaných plní funkci spíše přehledové příručky podrobných obsahů Ibsenových her. Sborník Ipsa, Ipsa, Ibsen, jehož redaktorkou byla taktéž zmíněná překladatelka, je tak v podstatě prvním zásadnějším pokusem o současnou recepci Ibsenova díla v kontextu bohaté a kontinuální české tradice inscenování Ibsenových her, a to pohledem divadelních praktiků, nordistů i literárních teoretiků.

2 Dostupné na: http://ibsen.nb.no/.

3 „Nær sagt alle hans levedager er kartlagt ned til mindste detalj.“ heslem „biografie Ibsen“ se nachází více než 520 odkazů na zahraniční i domácí studie, v čele s díly několika významných norských ibsenologů. ${ }^{4}$ Přesto nakladatelství Aschehoug u příležitosti příprav 100. výročí od smrti Henrika Ibsena oslovilo norského historika a literáta Ivo de Figueireda k sepsání nové biografie.

Dobře, že se de Figueiredo nezalekl výše uvedeného čísla ani zvučných jmen svých předchůdců..$^{5}$ Ke zkoumání ikony severského dramatu přistupuje s osobitým stylem; využívá principů vlastní metodologie, tzv. literární non-ficiton, která přináší příběh o muži, jenž „Thé nikdy nepije“, o době, v níž revoluce a divadelní hra mohou se jedním stát, a o čase, v němž drama může být poslem budoucnosti.

Namísto rozsáhlé odborné studie, kde by se to hemžilo citacemi, jmény a odkazy na odkazy s odkazy, se do českého prostředí dostává čtivá kniha, která velmi elegantně sesadila severského velikána z piedestalu ibsenovské mytologie.

4 Mezi hlavními studiemi, které zmiňuje I. de Figueiredio, jsou díla: Henrik Ibsen: Život spisovatele norského ibsenologa Halvdana Kohta (1928-1929), Michael Meyer: Henrik Ibsen (1967-1971) a Robert Ferguson: Henrik Ibsen: Nová biografie, 1996.

5 „ட̌́íkal jsem si, jestli mám být známý jako ten hlupák, který kývl na to, napsat o Ibsenovi biografii, nebo jako hlupák, který odmítl napsat biografii o Ibsenovi. Neměl jsem tedy moc na vybranou“, uvádí sám autor v rozhovoru pro portál Iliteratura u př́íležitosti křtu českého vydání. Dostupné na: http:// www.iliteratura.cz/Clanek/34699/figueiredo-ivo-de. 
Autor sám vnímal Ibsena ,jako muže, který dokázal herce i režiséry zároveň svazovat i osvobozovat. Stejně tak to činil se svými čtenáři a publikem“ (488). Ve stejném duchu pak funguje i sama biografie. Ivo de Figueiredo se nechal „svázat“ svým vzděláním a ve své práci velmi poctivě kombinuje dobová historická fakta s Ibsenovou rozsáhlou korespondencí a poznámkami ke hrám. Důslednou četbu dobové kritiky reflektující vydání jednotlivých her ve Skandinávii a dalších evropských zemích doplňuje o rozsáhlé recepce jednotlivých inscenací včetně vzpomínek a komentářů dalších významných osobností evropského literárního prostoru. Současně se ale „osvobozuje“ od dalšího budování ibsenovského mýtu. Autor se soustředí (jak ostatně sám název napovídá) na postupné odhalování masky, na které Henrik Ibsen sám velmi pečlivě po celý svůj život pracoval. Nejde však o žádnou násilnou demytizaci, ale spíš o otevřenou hru se čtenářem. Figueiredo volně střídá pozici historika a literáta, pokorného průvodce Ibsenovým životem i lehce ironického glosátora jeho uměleckých i lidských snah o své místo na divadelním nebi.

Uvádí nás např. do literárního kulturního prostředí Ríma v šedesátých letech 19. století, kde Ibsen prochází zásadní iniciační proměnou. „Rím byl místem a bytím mimo svět, místem, kde se umění, architektura příroda i samotný život daly pěstovat daleko od hluku světa“ (195). Tím „hlukem světa“ se myslí zuřící šlesvicko-dánská válka (1848-1851), která Ibsena zasáhla v mnoha směrech. Zbabělý postoj zemí Norska i Švédska, které Dánsku neposkytly pomoc, znamenal konec skandinavismu, jehož byl Ibsen velkým zastáncem. Přestal věřit v „ducha lidu“ i budování národa obecně, čímž se definitivně rozešel se svým původním literárním programem národního romantismu. Chopil se tedy role „dramatika se štírím ${ }^{6}$ perem“ a napsal v roce 1866 Branda ${ }^{7}$ který změnil vše: Na pozadí římského bohémského života, kde Ibsen obklopen sochaři a malíri místního Skandinávského spolku, ${ }^{8}$ zažívá poprvé pocit duševní svobody, se rodí i ibsenovská maska „kritizující, cholerický a pravdu požadující básník prorok“ (213). Ze zadluženého Ibsena v obnošených starých šatech se v Římě stane tajemný muž s licousy a kozinkovými rukavičkami. „Ibsenova proměna byla tak dramatická, až se jeho skandinávští přátelé domnívali, že se z něj přes noc stal jiný člověk“ (215). Téhož roku také po opakovaných žádostech obdržel od Norského království trvalý spisovatelský plat, což ovšem nijak neovlivnilo jeho kritický postoj k norské společnosti.

De Figueiredo nejprve velkoryse načrtává myšlenkový i společenský pohyb druhé poloviny 19. století, spojený s celkovou proměnou politické mapy Evropy, aby do něj poté vsadil Ibsena jako postavu dramatu světa, v němž postupně sehrával chtěné i nechtěné role - od proroka a revolučního dramatika přes tragikomickou postavu večírků, vděčného nositele všech možných řádů a ocenění až k nechtěnému bojovní-

6 Symbolika štíríího ostnu coby básnického pera, které zabodává do společnosti, patří mezi první Ibsenovy mýty o stvoření postavy literáta. Ibsen tvrdil, že při psaní Branda měl na stole štíra, kterého při psaní pozoroval, jak vstř́íkává jed do kousků ovoce, které mu podával.

$7 \quad$ Brand vyšel 15. 3. 1866 v nákladu 1250 výtisků a ještě téhož roku vyšly další dotisky přesahující 3000 výtisků.

8 Ke zř́izení spolku došlo v roce 1860, nebot do Říma byly přesunuty dánské, švédské a norské knižní sbírky. Ibsen se tehdy stýkal např. s kunsthistorikem L. Dietrichsonem a jeho ženou malî́skou M. Dietrichsonovou, sochaři H. J. Budalem a Ole Fladegerem či šlechticem a básníkem C. Snoilskym. 
kovi za ženskou emancipaci či vášnivému konzumentu sardinek.

Jednotlivá dramata pak buduje jako samostatné příběhy, v nichž se odráží jak postupná proměna Ibsena „z obyčejného kamene v mramor“ (13), tak přerod nacionálně romantického dramatika v provokativního avantgardního tvưrce moderního dramatu. Autor se nepouští do dlouhých interpretací jednotlivých her, ale provází čtenáře velmi pečlivě celým procesem vzniku textu od první inspirace až k výslednému jevištnímu tvaru a ohlasům premiérových uvedení na evropských scénách. Důležitá však nejsou primárně samotná historická fakta nebo okolnosti Ibsenova života, ale způsob, jakým jsou dávány hry do kontextu s tím, jak byly tehdy čteny a vnímány.

Brandem počínaje se každá další Ibsenova hra stala kulturně-společenskou událostí, která měla nebývalý dosah. Kromě bouřlivé diskuse kritiků a umělecké elity zasahovala i laické publikum ve městech i na venkovech. Např. záhy po vydání Domečku pro panenky (Nory) ženy opouštěly své snoubence, nebot’ v nich viděly „helmerovské rysy“. Přizraky už byly naprostým skandálem, který tehdejší norský tisk označil za zcela „nevhodný na sváteční stůl v křestanské domácnosti“ (415). Přední norský kritik Arne Garborg šel ještě dále a rozhořčoval se nad tím, že by „vize budoucnosti měly být servírovány v omáčce ze syfilidy a sajrajtu“ (414). Lepší reklamu si Ibsen nemohl přát a uměl toho náležitě využít. Tak, jak uměl pečlivě vybudovat jednotlivá dějství, pracoval soustavně a velmi koncepčně na vytváření knižního trhu se svými díly i na budování vlastního obrazu. Vedl rozsáhlou korespondenci s divadly ohledně prvních uvedení. Jeho dvorní vydavatel Frederik Hegel disponoval rozsáhlým seznamem adres, na něž putovaly výtisky přímo z tiskárny. Postupně také rozšíríil sít svých překladatelů, čímž razantně vstoupil do evropského prostoru. Zlomovým dílem byla v tomto směru Hedda Gablerová, která vyšla 16. prosince 1890 v úctyhodném nákladu 10000 výtisků. De Figueiredo nás opět nejprve seznámí s procesem vzniku celé hry, velký prostor ale navíc věnuje přijetí Ibsenových her obecně nejen ve Skandinávii, ale i v Německu, Francii a Anglii. Na pozadí dobových ohlasů se de Figueiredo pouští do vlastních velmi bystrých úvah nad ústředními tématy hry a přitom současně dodává cenné komentáře $\mathrm{k}$ tehdejším společensko-myšlenkovým náladám v jednotlivých zemích. V těchto dobře vystavěných kulisách mnohem lépe chápeme, proč Ibsen v Anglii zůstával dlouho provinčním autorem, jehož Př́zraky byly „shledány coby nevhodná obloha k jehněčí biftečkům a yorkšírskému pudingu“ (526). Zatímco naopak ve Francii Ibsena „přivinuli na hrud' mladí naturalisté“ (529) v čele s Andrém Antoinem (529).

K dokonalé hře se čtenářem patří i to, že samotnou kapitolu o Heddě Gablerové nazval autor „Pantofle a pistole“ a hned v úvodu neopomene dodat: „Je ironií, že tato hra vyšla pouhých několik měsíců poté, co se sám [Ibsen], natrvalo vrátil do Norska. V roce 1864 opustil rodnou zemi, aby psal hry, které byly přednostně namířeny vůči norské a skandinávské veřejnosti a když se vrátil v létě 1891 domů, byly jeho hry na dobré cestě, aby dobyly celou Evropu“ (515).

Samotné členění knihy je současně jedním z důležitých klíčů, jak k celé biografii přistupovat. Ačkoliv základní časová osa života a díla zůstává zachována, nenajdeme tu žádné tradiční „škatulkování“ Ibsenových her. Hlavními orientačními body jsou 
v knize města a místa, kde se Ibsen pohyboval. Ibsenův život a dílo je tedy cestou vedoucí z kostelní věže v rodném Skienu, přes Drážd’any a Mnichov se zastávkami u alpských jezer, v italských vesničkách, zpět k norskému fjordu, až do jeho poslední pracovny v Arbinově ulici v Kristianii. Autor ale záměrně nepodpořil součást Ibsenovského mýtu o zavrženém Norovi, který je nucen prožít většinu svého života v exilu. Motiv cesty je tu chápán v mnohem širším symbolickém smyslu a umožňuje knihu číst na několika úrovních, a tím si hledat i „vlastní cestu k Ibsenovi. Jednotlivé názvy podkapitol fungují jako další rozcestníky, které umožňují vydat se dále různě značenými směry. S humorem, nadhledem a nečekanými výhledy do ibsenovské zvrásněné krajiny.

Hlavní cesty, které se v knize stále protínají, jsou zřejmé: Ibsen - člověk a Ibsen maska. Masku však de Figueiredo chápe spíše jako „zatvrdlý zevnějšek jeho vlastní přirozenosti“ (13), proto se snaží spíše upozorňovat než násilně demaskovat, a to s plným vědomím, že současně i on sám přidává pár nových odlitků. Tento hlavní dialog opět dobře vystihují už samotné názvy kapitol „Státní satyr“ - „Nepřítel společnosti“ - „Henrik Ibsen Superstar“ „Sfinga a její zlaté žíly“.

Rozsáhlost i styl knihy si v zásadě vynucuje vlastní způsob četby včetně delších či kratších zastávek podle preferencí čtenáře, tedy závěrem několik doporučených tras:

1. „Il Cappellone“ - „Sežeň mi nakladatele“ - „Mnichovské intermezzo“ - „Jako skald u vévodových nohou“

Začínajícího dramatika (či spisovatele obecně) mohou např. zasáhnout kapitoly věnované evropským literární bohémě a spol- kům druhé poloviny 19 . století, $^{9}$ v nichž Ibsen nacházel kromě setkání s evropskou uměleckou elitou i prostor pro kultivaci či eskalaci svého ideového programu. Sám zažil několik doslova iniciačních setkání jako večeře s $\mathrm{H}$. Ch. Andersenem v roce 1870 nebo např. pobyt u vévodů Meiningenských v roce 1886 . V praktické rovině pak mohou být velmi inspirující taktéž pasáže o postupném budovaní dokonalého obchodního trhu, marketingové strategie, včetně řady praktických triků, jak si zajistit trvale vysoký náklad svých děl. A v neposlední řadě lze sledovat samotné vybudování mezinárodní značky Ibsen.

2. „Korespondenční režisér“ - „Too far from Piccadilly“ - „Der Wassermann“ „Francouz v Christianii““

Divadelní vědce, dramaturgy a režiséry určitě potěší (kromě velkého prostoru věnovanému recepci Ibsenových děl a setkání Ibsena s evropskou divadelní elitou od G. B. Shawa, A. Antoine, Lugné-Poa až po J. Joyce) také pasáže věnující se konkrétním připomínkám Ibsena $\mathrm{k}$ jednotlivým hrám, i to, v jaké míře zasáhl Ibsen i do proměny tehdejšího jevištního jazyka, režie i scénografie. Současně je možné nahlédnout přímo do Ibsenovské režijní kuchyně, protože de Figueiredo velmi poctivě zmapoval celé období ibsenova působení nejprve v Bergenském divadle (1852-1857) a posléze v Christanii (18571861), které navíc skončilo pod Ibsenovým vedením bankrotem.

9 Kromě zmiňovaného Skandinávského spolku v Římě se Ibsen zapojil do Mnichovského uměleckého okruhu, scházejícího se v kavárně v Achatzu, v tzv. spolku Krokodile, nebo v ateliéru Eilifa Peterssena. Při druhém pobytu v Ř́mě (1881) už Ibsen pořádal vlastní soaré pro vybrané umělce ze Skandinávie, Itálie a Německa. Mj. se v této době seznámil i s Camillou Colettovou. 
3. „Z Bergenu do světa“ - „Skandinávec Kravská lejna, suspernorskost a sámprosebebytí"

Nordisté, politologové a sociologové mohou knihu vnímat jako otevřený diskurz o národní identitě. Navíc norské historické reálie provinčního menšího státu versus Evropa jsou nám blíže, než se může na první pohled zdát. Ibsenova proměna $\mathrm{z}$ provinčního umělce $\mathrm{v}$ Evropana je pozoruhodná i z čistě psychologického hlediska. Autor si všímá, jakým způsobem Ibsen dokázal proměnit své slabé stránky v klady. Jako svérázný buřič ze Severu mohl snáze porušovat estetické požadavky na umění, otevírat tabuizovaná témata, až se mu nakonec podařilo v sedmdesátých letech trvale proměnit evropskou divadelní scénu. Byl sice obeznámen s tehdejšími filozofickými směry, ale jako nezlomný autodidakt si v jednotlivých hrách budoval vlastní ibsenologii. ${ }^{10} \mathrm{~A}$ oč více se snažil být Evropanem, zůstával pravým Norem. ${ }^{11}$

Biografii lze číst taktéž jako velmi čtivý historicko-sociologický exkurz do promě-

10 Jediným př́mo zmiňovaným filozofem spojovaným s Ibsenem je $\mathrm{S}$. Kirkegaard, který ho nepochybně ovlivnil. Ibsen sám se však $\mathrm{k}$ jeho filozofii nikdy otevřeně nepřihlásil.

11 Z důležitých zastávek zmiňme především vztah Henrika Ibsena s životním přítelem i nepř́itelem Bjønsternem Bjørnsonem a kritikem Edvardem Brandesem. Oba měli na Ibsenovu tvorbu zásadní vliv. Bjørnson byl první důležitou osobností pro zahájení Ibsenovy kariéry, pak mu velmi dobře posloužil jako prrímý konkurent, proti kterému se Ibsen v celé své tvorbě zásadně vymezoval. Bjørnsona tedy Ibsen nahradil dlouholetým vztahem s významným dánským kritikem Edvardem Brandesem, který Ibsena považoval za hlavního zástupce nastupující moderny. Jeho tvorbu soustavně sledoval a poskytoval Ibsenovi důležité společensko-kritické zázemí.

Velmi osvěžující odbočky představují kapitoly věnované zpodobňování Henrika Ibsena v obrazech a sousoších, které v další rovině dotvářejí jak Ibsenovo vědomé budování vlastního autoportrétu, tak i začátek ibsenovského kultu. ny evropské společnosti v druhé polovině 19. století nebo velmi nevšední formu literárního cestopisu.

Osobně si dovolím troufale dodat, že biografie má i všechny parametry tzv. bildungsromanu 21. století a obstojí i jako suverénní literární non-ficiton. ${ }^{12}$

De Figueiredo v závěru knihy nehledá v jednotlivých hrách ani v Ibsenově životě jakýsi jednotící významový rámec, ačkoliv Ibsen toužil, aby jeho dílo bylo čteno s tzv. svrchovaným záměrem. Vychází z předpokladu, že Ibsenova tvorba „se vyvíjela dialogicky, takže každá hra komentuje hru předchozí" (206) a neustále opracovává ústřední téma svobody jedince vưči společnosti.

A tento dialog probíhá i na úrovni jednotlivých dramatických postav s Ibsenem člověkem i maskou. Např́klad Brand a Peer Gynt jsou první výzvou k oproštění se od kompromisů, hodnotového i morálního rámce, který znemožňuje zasvětit život ideálům. Oscar (Přízraky), Hedvik (Divoká kachna) či Nora jsou pak prvními zástupci tohoto nového individualismu, kterým ale společnost stále stojí v cestě. $V$ dalších postavách se tento postoj ještě radikalizuje až k sebevraždě Heddy Gablerové či k smrtelnému pádu Stavitele Solnesse z vysněného domu. Všechny tyto postavy zrcadlí různé fáze Ibsenova zápasu o suverénní postoj umělce nezávislého na náladách a konvencích společnosti, ačkoliv si souběžně a vědomě budoval jasnou pozici prímo uprostřed společenského dění. Duševní aristokrat, vyžadující zvláštní zacházení,

12 Samozřejmě kniha zůstává stále rozsáhlým Ibsenovým životopisem, v němž hraje významnou roli Ibsenova rodina - manželka Suzanne a syn Sigurd, kterou de Figueiredo trefně označil za „stát Ibsen“, Ibsenovy mladé múzy i rozporuplné vztahy s několika málo přáteli. 
ničím nerušený pracovní režim a královské pocty vedl svůj druhý taktéž „maskovaný“ život ve svých hrách, a poskytl tak rozsáhlou živnou půdu pro různé způsoby interpretací či př́ímo dekódování jednotlivých replik v souvislosti se svým životem. Ale jak lze odhalit člověka, kterého velmi trefně charakterizovala první žena, která v Dánsku Ibsena uvedla, J. L. Heibergová: „Člověka to rozčiluje, když sedí u takového ohně a přitom mrzne" (279).

De Figueiredo se stal velmi pozorným a dobrým čtenářem Ibsenových dramat. Biografie má v sobě taktéž velkou dávku ambivalence a mnohoznačnosti, řemeslnou zručnost, smysl pro dramatické napětí, dějovou zkratku i postupné odhalování „koster z minulosti““. Její vydání sice nevyvolalo skandál, ale rozvírílo hladinu nad Ibsenovým odkazem směrem $\mathrm{k}$ současnosti. Jak dnes naložit s dědictvím „nesmrtelného velikána“, který svůj kult postavil na obrazu outsidera společnosti, neotesaného Seveřana, který ale nakonec svým dílem reformoval evropské moderní drama? Do jaké míry dnes rezonuje téma duchovního a etického postavení umělce ve společnosti? Jak se vlastně liší současný český Ibsen od německého? Ibsen by řekl: „Já se jen ptám, mým cílem není odpovídat.“ De Figueiredo alespoň napovídá: ,Jedna věc, je obdivovat dílo, druhá naopak být sveden prorokem. ,Ibsen` byl vždy něčím víc, než jen ,textem', byl moderním evropským kulturněhistorickým fenoménem." (607)

A já dodávám i velmi zajímavou dramatickou postavou. Biografie je doslova hozenou rukavicí pro současnou českou divadelní scénu, která by právě v roce 110 . výročí Ibsenova úmrtí mohla dát knize divadelní rozměr.

P. S.

Ibsenovo dílo $\mathrm{v}$ původním jazyce zahrnuje asi 60000 tiskových stran. „Náš český Ibsen“ nám v knihovně může zabírat prostor zhruba mezi půl metrem a metrem (podle typu sebraných spisů). Bez ohledu na to, kolik Ibsena máte doma, těchto 671 stran by vám tam rozhodně nemělo chybět.

DOI: 10.5817/TY2016-1-19

13 Jediné, co by se dalo de Figueiredovi vytknout, je velmi dobrý smysl pro humor, který Ibsenovi podle všeho zásadně chyběl. 